\title{
Chronology of a protest
}

\section{By UNI TAVUR}

Friday, June 15: Students hold a Student Union Day at the University of Papua New Guinea. The day is divided into two parts. The morning session is devoted to discussing problems of not enough lecturers, outdated books in the library, limited academic weeks, an expensive bookshop and other issues affecting the university.

Student Representative Council (SRC) president Augustine Moionges is in Mount Hagen and vice-president Kalogo Gima takes charge of this forum.

Afternoon session opens debate on the World Bank (WB) and international Monetary Fund (IMF) initiated land mobilisation programme. Students express concern about the Government being used by the two monetary organisations to "sell" Papua New Guinea to foreign developers.

By the end of the day, students declared war on the WB and IMF!

Saturday June 16: SRC members travel by boat to Motupore Island outside Port Moresby and hold a secret meeting. Minutes of the meeting are unknown.

Monday June 18: Most students are unaware that a strike is looming. They prepare for normal classes; SRC president Augustine Molones returns from Mt Hagen and calls on the students to stop attending classes and to attend a forum. He terms the boycott of classes as "voluntary". Students continue heated debates on privatisation and land mobilisation issues. The forum gets emotional.

Tuesday June 19: Students decide to "voluntarily boycott" classes again and remain at the forum area. After lunch, the SRC sends out parties to carry out awareness campaigns in all major suburbs of Port Moresby. The focus of the awareness is the WB. IMF, privatisation and land mobilisation, SRC also seeks assistance from the Electoral Commission to conduct a referendum at the university.

Counting of votes takes place at the Electoral Commission's office at Boroko overnight.

Wednesday June 20: In the morning, the SRC announces the results of the counting and declares that majority voted for strike action. The strike is to 
last until Friday, June 22. Students go out to carry out a'vareness campaigns and also to mobilise support for the strike. The university administration warns students that the strike and referendum are illegal and urges everyone to return to classes.

Thursday June 21: Students continue awareness programme and attract hundreds of people to the Prime Minister's office at Waigani. All public motor vehicles (PMV) halt operations in support of the students. Most government offices at Waigani shut down. The SRC students and the public demand that Prime Minister, Sir Mekere Morauta, come out and receive their petition.

However, Sir Mereke sends cabinet ministers Philemon Embel (Provincial Affairs), John Pundari ((Foreign Affairs). Peter Ipatas (Mining) Ben Micah (Privatisation Commission chairman) and Police Commissioner John Wakon, but the crowd refuses to give them their petition.

Still the Prime Minister does not show up. The crowd decides to spend the first night around the old Pineapple building and outside Morauta House where Prime Minister's office is located.

Friday June 22: The crowd wakes up and waits for the Prime Minister all day. Police block vehicles from entering the Waigani government offices. PMV routes $7,8,11$ and 15 had to be detoured. All buildings in the Waigani government offices have closed doors and hundreds of public servants stay out from work.

By $6 \mathrm{pm}$, it becomes evident that the Prime Minister would not meet the people. But the crowd is determined and decides to spend the second night sleeping outside on the car park and PM's office. In the night, police attempt to disperse the crowd but the crowd ignore the police presence and continue praying and singing the national anthem and police give up.

Saturday June 23: Over the weekend, there is no communication between the PM and the SRC. The crowd keeps growing - reaching to about 15,000 - and the SRC reminds the people that they were to spend this night outside the PM's office as well. This is the third night; the crowd sleep outside the PM's office.

Sunday June 24: The large crowd still waits at the gates of Morauta House. 


\section{CHRONOLOGY OF A PROTEST}

The university is almost deserted as students decide to take up temporary residence at the PM's office gate.

SRC arranges transport for students to travel between the campus and Morauta House. Students return to the campus for shower, rest and meals before they return to the PM's office. Students and their supporters spend the fourth night outside.

Monday June 25: This time, the crowd is even bigger than before - about 20,000 plus as they wait for the Prime Minister. Around 12 noon, the Prime Minister sends word out that he would be meeting the protesters. Finally, Sir Mekere is escorted under very heavy guard.

The SRC presents its petition and gives the PM 24 hours to reply. While receiving the petition, the Prime Minister explains to the protesters that he will give some but not all answers the next day. Sir Mekere tells the crowd that some of the decisions have to be made by the Cabinet. In the meantime, he urges them to return to their homes. After the Prime Minister leaves, the SRC leaders tell the crowd that they were to spend the night outside and get their answers tomorrow. The protesters again agree to sleep outside Morauta House.

12 midnight: Heavily armed police personnel arrive at the Waigani government offices and order the people to leave the area within 15 minutes, but the protesters still maintain their positions. After three warning shots, the police fire tear gas canisters into the crowed and forcefully chase the crowd out of the area.

As the crowd disperses, it becomes violent. Along the way at the Administrative College near UPNG, two cars are burnt. Another car is burnt at the university's main entrance. Around university's main bus stop, a fourth car is burnt. Stones, bottles, and bricks being thrown by angry protesters damage many cars travelling along the main highway. The Big Rooster outlet at Rainbow is burnt down by arsonists and fire fighters travelling to fight the fire get stoned. Plants, signposts and streetlights along the Waigani Gerehu road are destroyed.

Police arrive at the scene and chase both students and members of the protesting public into the university premises.

It is during this period that students are eventually shot and some are 


\section{CHRONOLOGY OF A PROTEST}

wounded. Police concentrate heavy gundfire into the air and sometimes directed at the students.

The gunshots are heard in many parts of the the city. Police also fire lots of gas canisters into the campus. The bullets and tear gas do not deter the students.

The gunfire continues until 7am Tuesday morning, when the police withdraw and take up position at the Waigani police station.

Tuesday, June 26: The city of Port Moresby comes to a standstill as students continue to fight police with saticks and stones. A large crowd from Gerehu (stages 1-6), Rainbow, Moarata (1, 2 and 3), Ensisi, Waigani and Tokarara join the students. People from other areas too come in large numbers and demand the police allow them through to the Prime Minister's office for answers to their petition.

There is general disorder, destruction and looting in all parts of the city. However, the police refuse to let the crowd pass. Tensions between police and protesters mount and finally the crowd go on a rampage. Police fire rubber bullets and tear gas into the crowd and chase the thousands of people away.

The Governor-general declares a curfew in Port Moresby.

Wednesday, June 27: Students mourn the death of fellow students and anxiously await the news of those in hospital.

Wednesday, July 4: Funeral attended by about 3000 plus students, city residents, friends and relatives. 